\title{
PERUBAHAN DARI SEKOLAH DENGAN BOSS-MANAGEMENT KE SEKOLAH DENGAN LEAD-MANAGEMENT
}

Penjelasan soal tersebut di atas dapat diilustrasikan dalam paparan William Glasser, yang membahas terkait boss-management ke sekolah dengan lead-management, yang sangat penting dalam gerakan quality school, begitu juga bagaimana sekolah tersebut melakukannya untuk menciptakan belajar bermutu pada diri anak.

William Glasser, menjelaskan bahwa hanya melalui "lead-management" guru dapat membuat ruang kelas di mana semua siswa tidak hanya melakukan pekerjaan yang kompeten tetapi mulai melakukan pekerjaan yang berkualitas, kelas yang seperti itu adalah inti dari sebuah sekolah yang berkualitas. Untuk membujuk siswa membentuk sekolah yang berkualitas, guru harus terlebih dahulu menerapkan kehangatan/keakraban pada siswa, hubungan yang benar-benar tanpa paksaan dengan siswa mereka; mengajar hanya dengan bahan materi yang bermanfaat, yang berarti menekankan keterampilan daripada hanya meminta siswa untuk menghafal pelajaran; dan bergerak dari evaluasi guru untuk evaluasi diri siswa.

Glasser berpendapat bahwa di sekolah, para siswa merupakan para pekerja, dan mereka yang mengelola di sekolah adalah para guru. Guru bertugas untuk memanage siswa secara langsung, sedangkan guru dimanage oleh administrator. Walau sebagian besar para guru telah berusaha sangat keras untuk bisa mengatur siswa, tetapi belum sampai mengetahui bagaimana memanage siswa hingga bisa meningkatkan kualitas kerja yang signifikan. Dengan ini William Glasser memberikan contoh dan mencoba menjelaskan berbagai praktekpraktek yang sangat sukses dalam kinerja. Hal ini dijelaskan oleh Glasser agar bagaimana manager sekolah dapat belajar dari kesuksesan tersebut. Yang penting dari praktek-praktek ini bahwa mereka secara khusus bertujuan membujuk para pekerja untuk bisa melakukan pekerjaan yang bekualitas tinggi.

Glasser mencontohkan salah satunya adalah praktek yang di lakukan oleh Dr. W. Edward Deming, orang Amerika yang mengajarkan Jepang untuk mencapai kinerja kualitas tinggi dengan biaya yang rendah. Deming bekerja selama tiga puluh tahun lebih di Jepang sebelum beberapa industrialis Amerika menaruh perhatian kepadanya. Di bawah manager Deming, untuk pertama kalinya dibuat produk berkualitas tinggi seperti mobil dan elektronik untuk kalangan menengah ke atas.

Lebih jelasnya Glasser menyatakan bagaimana ide-ide Deming dapat diadaptasi ke sekolah-sekolah. Di mana biasa hanya beberapa siswa yang terlibat dalam pekerjaan yang 
berkualitas tinggi, akan diganti dengan sistem di mana hampir semua siswa memiliki pengalaman tersebut. Setelah mereka memiliki pengalaman itu, siswa akan merasa sangat puas. Mereka tidak akan menolak kesempatan untuk terus melakukan pekerjaan semacam ini. Oleh karena itu Glasser mengatakan lebih jauh bahwa para siswa tidak hanya sebagai para pekerja di sekolah, namun mereka juga merupakan produk, begitu mereka melihat bahwa mereka sendiri yang mendapatkan kualitas tersebut dalam diri mereka masing-masing.

Untuk membantu administrator dan guru dalam menerima ide-ide baru mengenai manajemen, Glasser menjelaskan prinsip-prinsip teori kontrol yang telah diidentifikasinya selama sepuluh tahun. Teori kontrol mengungkapkan, jauh lebih baik daripada teori yang ada, baik mengapa dan bagaimana kita semua berperilaku (teori kontrol yang berkaitan dengan pengelolaan kualitas).

Banyak fakta bahwa guru sekolah umum mulai putus asa untuk pendidikan yang lebih baik bagi anak-anak mereka sendiri, jika kuat secara finansial, mereka akan mengirim anakanak mereka ke sekolah swasta, yang mereka percaya bahwa sekolah swasta dapat melakukan pekerjaan yang lebih baik dan berkualitas dibanding sekolah-sekolah umum. Hal ini akan jadi sangat sulit mendefinisikan seperti apa kualitas pendidikan yang tepat untuk semua situasi. Namun, kita hampir dapat selalu mengenali kualitas pendidikan ketika kita melihatnya. Jika ditanyakan pada setiap administrator sekolah, pasti mereka akan memperlihatkan atau menunjukkan kita beberapa pekerjaan berkualitas tinggi dalam setiap mata pelajaran. Dan hal ini meyakinkan Glasser bahwa kita yang melihatnya akan setuju bahwa apa yang ditampilkan pada kita adalah sebuah kualitas.

Sebagian besar dari mereka yang peduli dengan masalah-masalah sekolah belum terfokus secara khusus pada bagaimana siswa dikelola di sekolah. Ketika ditanya untuk solusi, baik itu para profesional dan nonprofesional dalam pendidikan menjawab bahwa bentuk pengajaran yang lebih baik adalah jawabannya, tanpa menyadari bahwa seperti apa pengajaran yang mereka anggap benar-benar baik. Sebagian dari mereka mengatakan bahwa mengajar yang lebih baik, tentu saja bekerja lebih keras dan belajar lebih banyak dari pengalaman beberapa guru dan orang lain.

Selain itu, sebagian besar siswa juga memiliki keluhan utama. Mereka mengeluhkan bentuk pengajaran yang membosankan. Glasser menjelaskan kata "Boring” biasanya berarti bahwa kita tidak bisa menghubungkan apa yang diminta untuk kita lakukan dengan bagaimana kita mungkin menggunakannya dalam kehidupan kita. Sebagai contoh, pengajaran membosankan yang mematikan yaitu menghafal, fakta bahwa baik kita, atau siapa pun yang 
kita tahu, pasti pernah merasakan bentuk pengajaran ini. Padahal ukuran yang paling jelas dari guru yang efektif yang selalu diingat adalah guru yang tidak membosankan.

Glasser menyatakan mungkin ini perbedaan utama antara seorang guru yang mengerti perannya sebagai seorang manajer dan yang tidak; manajer bersedia mengeluarkan berbagai usaha untuk memberikan pekerjaan yang tidak membosankan karena ia tahu bahwa hampir tidak mungkin bagi pekerja untuk bosan melakukan pekerjaan yang berkualitas tinggi. Dalam teori kontrol Glasser, bahwa guru adalah manajer yang baik dan tidak membosankan karena ia telah menemukan cara pengajaran yang memudahkan bagi siswa untuk memenuhi kebutuhan dasar mereka ketika mereka bekerja. Jika guru tidak memberikan pengajaran agar kebutuhan para siswa terpuaskan, secara tidak langsung maka mereka memberikan paksaan untuk membuat siswa belajar. Guru yang efektif mengelola siswa tanpa paksaan. Sedangkan guru kurang efektif mungkin hanya prihatin tentang siswa secara pribadi, ketika mereka mengajar mereka masuk ke dalam praktik yang bersifat memaksa yang akhirnya merusak efektivitas mereka. Guru koersif adalah aturan, bukan pengecualian, di sekolah. Tapi, jika jumlah guru yang mengelola siswa tanpa paksaan meningkat, itu adalah solusi untuk masalah mendesak ini.

Dari apa yang telah muncul yang tampaknya efektif ini merupakan fokus baru pada perubahan struktur sekolah, dan konfigurasi baru yang paling populer sebagai daya tarik sekolah. Di sini, baik guru dan siswa memiliki lebih banyak pilihan: Guru dapat mengajar lebih dari apa yang mereka nikmati, dan siswa dapat belajar lebih banyak dari minat mereka. Ketika ini terjadi, tidak ada kebutuhan untuk paksaan. Sudah ada bukti jelas bahwa baik siswa dan guru bekerja lebih keras dan melakukan lebih banyak pekerjaan berkualitas di sekolah-sekolah yang memiliki daya tarik. Tapi, dokumen penelitian yang dipublikasikan bahwa sekolah yang menarik dan sekolah struktural inovatif lainnya juga dapat gagal jika manajemen koersif tradisional berlaku. Ini bukan karena struktur mereka rusak tetapi karena, setelah awal yang baik, banyak guru yang membuat upaya sukses untuk memperbaiki cara mereka memanage siswa terhambat oleh administrator yang memberitahu mereka bahwa kualitas kerja baik mereka dan yang siswa lakukan tidak dapat diterima.

Hal ini diilustrasikan dengan baik oleh akademik yang sama dari Boston Tea Party:

Sekelompok senior di Sekolah tinggi Torrance akademis, dengan sengaja gagal dalam tes terbaru Program Penilaian California, ini dilakukan dalam upaya untuk mengirimkan pesan kepada administrator yang mereka percaya terlalu banyak menempatkan penekanan pada ujian. . . . badan mahasiswa Presiden Kelle Price, mengatakan bahwa dia tidak sengaja gagal tes, beberapa senior menjadi tidak puas 
ketika beberapa guru kelas diganggu untuk mempersiapkan tes. Dia mengatakan siswa juga percaya bahwa administrator-yang mengunjungi kelas untuk menekankan pentingnya melakukan tes dengan baik-terlalu peduli untuk mempertahankan citra sekolah. . . . Bill Franchini, yang mengepalai Asosiasi Guru Torrance,. . . mengatakan tekanan dimulai dari departemen negara. . . dan bekerja secara turun menurun melalui distrik sekolah lokal, kepala sekolah, guru dan akhirnya siswa. "Saya pikir mereka (mahasiswa) seperti pion dalam permainan yang jauh lebih besar," katanya.

Penilaian tersebut benar. Siswa yang cerdas ingin pendidikan yang berkualitas tinggi dan untuk melakukannya, mereka memberontak terhadap paksaan dari atas ke bawah, mereka percaya bahwa pemaksaan pasti akan melahirkan pemaksaan.

Hal ini penting untuk disadari bahwa salah satu alasan untuk keberhasilan sekolah yang memiliki daya tarik adalah bahwa tidak adanya guru yang memaksa. Kita harus ingat bahwa kekuatan inovasi bahwa hal itu tidak meningkatkan jumlah orang yang efektif, tetapi memberikan orang-orang yang efektif memiliki kesempatan yang lebih baik untuk menunjukkan efektivitas mereka. Oleh karena itu, kekurangan guru yang efektif bukan masalah yang bisa diselesaikan dengan struktur baru. Hal ini disebabkan oleh bagaimana kita melatih dan mengelola guru dan hanya dapat diselesaikan dengan memperbaiki cara kita melakukan hal tersebut, tidak peduli apa struktur sekolah. Manajer guru yang efektif akan efektif dalam lingkungan sekolah, tetapi mereka akan kurang efektif jika mereka dikelola secara berbeda dari cara mereka mengelola siswa.

Jika melalui administrasi yang lebih baik kita dapat meningkatkan jumlah guru yang efektif, kita akan segera melihat berbagai perbaikan struktural di banyak sekolah, perbaikan yang dilakukan mungkin dibawa oleh meningkatnya kepercayaan diri guru, lebih profesional dan, karena mereka, siswa melakukan kualitas kerja yang lebih keras untuk bekerja. Menciptakan sejumlah besar sekolah dengan daya tarik sebelum memperbaiki manajemen sekolah ke titik di mana lebih banyak siswa yang terlibat dalam kualitas kerja adalah meletakkan kereta di depan kuda.

Buku ini bicara tentang mengelola sekolah untuk mendapatkan kualitas dan, dalam melakukannya, setiap sekolah bergerak ke arah yang apa Glasser sebut sebuah sekolah yang berkualitas. Glasser fokus pada bagaimana guru dapat mengelola siswa lebih efektif dan bagaimana administrator dapat menggunakan metode yang sama untuk mengelola guru. Metode manajemen Glasser menyarankan hal yang berbeda dari manajemen sekolah sekarang di sebagian besar sekolah-sekolah. Seperti yang dikatakan sebelumnya, ini didasarkan pada teori kontrol dan menggunakan metode kualitas W. Edwards Deming. Hal 
ini hampir tidak digunakan di sekolah-sekolah, namun saat ini sedang digunakan dengan sukses besar di beberapa perusahaan seperti Ford Motor Company.

Meskipun mungkin ada awal dari sebuah revolusi manajemen dalam beberapa industri-industri besar, bahwa perubahan ini telah jauh menyebar luas, dan hampir tidak ada yang telah mencapai sekolah. Di sini, seperti di sebagian besar industri, guru dan siswa dikelola dengan cara yang sama, bahwa orang telah berhasil selama berabad-abad, dengan berdasarkan metode kuno, teori "akal sehat" bagaimana itu berfungsi, yang disebut stimulusrespon. Tapi, Glasser menunjukkan ketika saya mulai menjelaskan teori kontrol dalam Bab Empat, teori stimulus-respon yang salah. Bila digunakan untuk mengelola orang, itu mengarah ke sebuah metode manajemen tradisional yang disebutnya bos-manajemen. Bosmanajemen tidak efektif karena mengandalkan paksaan dan selalu menghasilkan para pekerja dan manajer menjadi musuh. Komandoisme sangat sedikit hingga akhirnya menyebabkan kerja keras yang konsisten dan hampir tidak pernah ada kualitas kerja, dan di tempat industri lebih jelas daripada di sekolah. Mengelola kualitas menuntut metode baru tanpa paksaan, sebuah manajemen yang Glasser sebut lead-management.

Glasser, dalam teori Kontrol-nya di kelas berfokus pada bagaimana pengetahuan teori baru ini dapat membujuk guru menggunakan pembelajaran kooperatif untuk menggantikan metode ceramah dan daftar kerja individu. Walau sementara tanggapan tentang perubahan penting ini telah sangat positif, namun perkembangannya sangat lambat. Dan ini membuat Glasser semakin jelas bahwa kemajuan akan terus menjadi lambat sampai kita mampu mengubah sistem dari boss-management ke lead-management.

Glasser mencoba mengatakan bahwa kita tidak mungkin pernah pindah dari sistem boss-management ke lead-management kecuali kita bisa mengatasi kendala yang ada di jalan dimana perubahan perlu dilakukan. Ini adalah kegagalan kita untuk memahami bahwa begitu sulitnya untuk mengajar secara efektif. Apa yang membuat kendala ini begitu sulit untuk diatasi adalah bahwa kebanyakan orang, termasuk pendidik, tidak melihatnya sebagai hambatan. Kecuali jelas terlihat untuk apa itu, memiliki sedikit kesempatan bahwa itu akan bisa diatasi, karena hal-hal itulah, maka akan terus memblokir apa yang mesti dilakukan dalam mengubah cara mengelola siswa ataupun guru.

Hampir semua orang di masyarakat kita berbagi kesalahpahaman tentang mengajar. "semua orang" di masyarakat yang dimaksud Glasser adalah guru, orang tua, administrator, anggota dewan sekolah, politisi, wartawan pendidikan, dan bahkan dosen yang menjalankan program persiapan guru, hampir semua gagal memahami bahwa menjadi seorang guru yang efektif mungkin pekerjaan yang paling sulit dari semua pekerjaan yang ada. 
Glasser menjelaskan bahwa seorang guru yang efektif adalah yang mampu meyakinkan semua siswanya untuk melakukan pekerjaan yang berkualitas di sekolah. Semua bentuk-bentuk kegagalan sekolah misalnya, tingkat putus sekolah tinggi, nilai tes yang rendah, dan penolakan untuk mengambil pelajaran berat seperti matematika dan sains adalah hasil dari siswa yang gagal mengeluarkan upaya untuk melakukan pekerjaan yang berkualitas. Beberapa guru yang secara konsisten dapat membujuk hampir semua siswa mereka untuk melakukan pekerjaan yang berkualitas, tanpa diragukan lagi, bahwa guru tersebut berhasil di pekerjaan yang paling sulit ini.

Glasser berpendapat bahwa pada umumnya semua pekerjaan itu terbagi dua, yaitu: mengelola hal-hal (objek) atau mengelola orang (subjek). Ketika kita mengelola hal-hal, esensi dari pekerjaan ini adalah untuk melakukan operasi pada hal tersebut atau bahkan pada orang (yang mungkin bertindak pasif sebagai hal). Seperti halnya seorang guru, Glasser mengartikan guru adalah manajer, dan kebanyakan orang akan setuju bahwa siswa sebagai pekerja. Sambil mengelola pekerja atau siswa untuk meningkatkan kualitas pekerjaan mereka, guru diharap mengenal teori kontrol dengan baik, yang menjelaskan bahwa semua perilaku kita merupakan upaya untuk memenuhi kebutuhan dasar seperti cinta dan kekuatan, serta keterampilan maka dengan itu manajemen yang efektif tidak akan sulit untuk dipelajari. Sebagai contoh, semua siswa mungkin tampak sangat berbeda satu sama lain, namun mereka semua digerakkan oleh kebutuhan yang sama. Guru yang memahami hal ini akan menfokuskan banyak tenaga mereka dalam mengelola siswa untuk memenuhi kebutuhan mereka mengerjakan tugas sekolah.

Ada beberapa pengecualian untuk aturan umum bahwa sebagian besar manajer berurusan dengan pekerja yang cukup kooperatif. Sebagai contoh: sebagian kecil orang berpegang pada pekerjaan yang mereka benci dan akhirnya sering melakukan pekerjaan yang buruk karena mereka tidak tahu bagaimana untuk mendapatkan pekerjaan yang lebih baik. Bagian integral lain dari apa yang membuat sebuah pekerjaan merupakan bentuk kerja keras adalah beberapa manajer selalu disalahkan dalam melakukan pekerjaan yang buruk. Mereka yang tugasnya adalah untuk mengelola hal-hal (objek) yang biasanya cepat disalahkan ketika mereka melakukan pekerjaan yang buruk. Sebagai contoh, seorang tukang ledeng yang gagal untuk memperbaiki kebocoran cepat disalahkan atas kegagalan ini.

Mereka yang mengelola hal-hal (objek) lebih berada dalam kendali, dibanding dari yang mengelola orang (subjek), berarti bahwa meskipun mereka jelas subjek untuk disalahkan ketika mereka melakukan pekerjaan yang buruk, mereka dapat hampir selalu menghindar untuk disalahkan jika mereka melakukan upaya untuk melakukan pekerjaan 
dengan baik. Di sisi lain, mereka yang mengelola orang-orang (subjek) kurang jelas untuk dipersalahkan ketika orang-orang mereka melakukan pekerjaan yang buruk.

Glasser mengatakan sekarang ini kita dibanjiri dengan siswa yang melakukan hal buruk di sekolah, dan semakin banyak guru yang tidak percaya bahwa mereka yang bersalah, sedangkan mereka tetap disalahkan untuk apa yang mereka tidak tahu bagaimana untuk memperbaikinya atau disalahkan untuk apa yang mereka tidak bisa lakukan karena mereka (para guru) dikelola dengan buruk oleh administrator di atas mereka.

Faktor lain yang membuat mengajar seperti sebuah kerja keras adalah kurangnya gaji yang memadai untuk kerja keras tersebut. Jika kita menerima kenyataan bahwa kita perlu banyak guru yang lebih efektif, kita juga harus menghadapi kenyataan bahwa sebagian besar dari apa yang membuat pekerjaan mudah atau sulit adalah seberapa besar pembayarannya (gajinya). Glasser mengatakan, mengajar tidak akan pernah menjadi pekerjaan bergaji tinggi, tapi gaji rendah membuat pekerjaan mengajar akan menjadi lebih sulit. Setiap sistem reward yang dirasakan oleh para pekerja tidak adil, maka akan menciptakan kepahitan dan kebencian. Ini merupakan masalah membayar jasa dalam sistem mentor/guru, dan terkadang pembayaran jasa lebih didasarkan pada kriteria yang sewenang-wenang. Lanjut, Glasser menyatakan bahwa faktor lain yang membuat pengajaran sekolah umum yang efektif di negara ini (Amerika) jauh lebih sulit, dibandingkan dengan negara-negara lain, adalah bahwa kita tidak memiliki dukungan budaya yang kuat dari pendidikan yang dapat diambil, dibanding di negara-negara seperti Korea, Jepang, Perancis, dan Jerman.

Sebaliknya kata Glasser, ada juga pengajaran menjadi semakin sulit dikarenakan prestasi. Karena "prestasi" siswa semakin dipertanyakan oleh publik dan telah menjadi isu politik dari sebagian Negara, setelah negara "mengukur" pencapaian berdasarkan uji "objektif" dan menemukan skor terlalu rendah. Muncullah rasa takut bahwa mereka (para guru) akan disalahkan atas nilai rendah ini dan kekuatan mereka akan terancam, kemudian kebanyakan departemen negara memperkenalkan pengajaran "reformasi' yang secara langsung (dan, saya percaya, secara membabi buta) yang bertujuan untuk meningkatkan nilai ujian.

Sebagai peneliti, Profesor McNeil menanggapi hal tersebut, McNeil menulis:

Reformasi semacam itu membuat pengajaran dan kurikulum tidak autentik. Jika kita ingin melibatkan siswa dalam belajar, kita harus membalik proses ini. Bila pengetahuan sekolah tidak dapat dipercaya oleh siswa, mereka (para administrator) memilih untuk tidak mau menunggu sampai "nanti" untuk belajar "apa yang benar- 
benar perlu diketahui/dibutuhkan oleh siswa." Akhirnya muncullah kurikulum terpusat, tes hasil terpusat, dan perilaku guru standar dan ini semua hanya dapat membuat frustrasi para guru.

Pendekatan standar dan terfragmentasi sangat tidak memuaskan bagi siswa (dan guru), semakin banyak siswa yang secara aktif menolak dan melawan. Administrator sekolah kemudian jatuh ke dalam perangkap berpikir bahwa ini hanya masalah disiplin, bukan pendidikan yang tidak memuaskan, yang merupakan penyebab rendahnya tingkat pencapaian. Ini menjelaskan peningkatan penekanan pada peraturan ketat deportasi (lebih banyak pemaksaan), yang selanjutnya mendefinisikan siswa yang baik sebagai sesuatu yang pasif daripada yang terlibat, menanyai, bahkan kadang-kadang tidak setuju dengan pembelajar. Setiap metode pengajaran yang mengabaikan kebutuhan guru dan siswa pasti akan gagal.

Terperangkap dalam perangkap ini, banyak guru menyerah pada apa yang mereka yakini dan menerima pandangan politik bahwa siswa harus diperlakukan sebagai sesuatu dan diisi dengan fragmen pengetahuan. Untuk mengajarkan cara ini, mereka menekankan fakta dan jawaban "benar", menghindari kontroversi dan diskusi, memberikan banyak pekerjaan rumah, sering menguji, dan menyesuaikan apa yang mereka ajarkan untuk program pengujian negara. Dengan berbuat demikian, mereka menjadi jauh lebih impersonal. Mengajarkan lebih sedikit tentang apa yang ingin dipelajari siswa mereka daripada yang mereka rasakan benar. Tidak ada yang membuat pekerjaan lebih sulit daripada merasa bahwa Anda harus menyerah pada apa yang Anda yakini.

Glasser mengungkapkan, mungkin ada hambatan lain yang perlu diatasi jika kita beralih dari boss-managing ke lead-managing. Tetapi jika kita bisa mengatasinya, maka kita memiliki peluang bagus untuk mengatasi orang lain. Jika kita terus mengambil keterampilan dan seni mengajar secara sederhana, percaya bahwa hampir semua orang bisa melakukannya. Pengajaran adalah pekerjaan yang sangat sulit yang membutuhkan kompensasi yang cukup dan cukup banyak pelatihan kerja seumur hidup bagi guru.

Awal pembahasannya, Glasser jelas menyatakan bahwa, di sekolah, bossmanagement adalah alasan utama mengapa hanya sedikit siswa yang terlibat dalam penghargaan berkualitas tinggi atau penempatan kelas lanjutan. Dan selama boss-manager menang, hanya sedikit kemungkinan kita bisa meningkatkan jumlah kecil ini karena bossmanager benar-benar salah memahami apa yang telah menjadi salah satu kata kunci manajemen yang paling umum: motivasi. Boss-manager dengan tegas percaya bahwa orangorang dapat dimotivasi dari luar: Mereka gagal memahami bahwa semua motivasi kita berasal dari dalam diri kita sendiri. 
Glasser mengatakan, Boss-teacher dan administrator terus-menerus meratapi bahwa siswa tidak termotivasi, tapi yang sebenarnya mereka katakan adalah bahwa mereka tidak tahu bagaimana membujuk siswa untuk bekerja. Dan selama mereka terus percaya pada pemaksaan, mereka akan melakukan hal yang buruk. Ketika sampai pada pemahaman motivasi, boss-manager mencari sesuatu yang tidak ada. Tapi mereka terus mencari karena mereka hampir seperti semua orang, menerima teori stimulus-response. Menurut teori ini, perilaku kita hampir selalu termotivasi oleh stimulus yang ada diluar diri kita. Misalnya, kebanyakan orang percaya bahwa siswa berhenti berbicara karena guru meminta diam atau hukuman penjara mencegah kejahatan. Tapi teori kontrol menunjukkan bahwa ini bukan masalahnya. Siswa diam hanya ketika mereka percaya akan hal yang mereka lakukan seperti yang diminta guru; Jika tidak, mereka terus berbicara. Dan penjara dibuat dengan pelanggar hukum yang telah ada sebelumnya dan tidak terhalang oleh pengalaman itu.

Boss-teacher menyuruh siswa setiap hari untuk bekerja keras; meski mereka dihukum, banyak siswa masih belum bekerja keras. Sebenarnya, banyak yang melakukannya bahkan setelah mereka dihukum. Fakta ini tidak mengganggu boss-teacher; mereka terus percaya bahwa mereka dapat membuat siswa melakukan apa yang mereka katakan, jika saja mereka dapat mengetahui cara yang lebih kuat untuk memberi tahu mereka. Salah satu indikasi dari hal ini adalah bahwa lebih banyak guru daripada masyarakat umum percaya bahwa mereka seharusnya memiliki hak untuk memukul anak-anak.

Glasser tidak mengatakan bahwa apa yang terjadi di luar kita tidak berarti apa-apa. Apa yang terjadi di luar kita banyak berhubungan dengan apa yang kita pilih, tapi kejadian di luar tidak menyebabkan perilaku kita. Apa yang kita dapatkan, dan semua yang bisa kita dapatkan, dari luar adalah informasi; Bagaimana kita memilih untuk bertindak berdasarkan informasi ini terserah kita. Oleh karena itu, informasi yang didapat siswa dari guru, yang mencakup bagaimana informasi ini diberikan, sangat penting. Tetapi para siswa adalah orang-orang yang membuat keputusan akhir tentang betapa pentingnya hal itu bagi mereka. Yang lebih penting yang mereka pikirkan, semakin mereka akan melakukan apa yang mereka minta dan semakin baik mereka akan melakukannya.

Kemudian Glasser mengumpamakan, jika saya mengarahkan pistol ke arah Anda dan meminta dompet Anda, keseluruhan urutan tersebut merupakan informasi. Anda akan melakukannya, dan hanya melakukan apa yang terbaik menurut anda. Sebagian besar dari Anda akan menyerahkan dompet Anda karena Anda memutuskan bahwa hidup Anda lebih penting daripada dompet Anda, tapi beberapa di antara Anda ada yang berbeda, ada yang tidak akan melakukannya. Perbedaan antara lead-manager dan boss-manager ada dalam 
informasi yang diberikan masing-masing kepada pekerja-atau siswa, dan ini adalah perbedaan besar; Dalam praktiknya, ini adalah perbedaan utama antara siswa yang bekerja atau "bersandar pada pegangan mereka." Pesannya, dari boss-manager selalu bersifat memaksa, baik itu dalam memberikan penghargaan atau hukuman, karena bos menganggap bahwa ini adalah cara terbaik untuk " Memotivasi "pekerja. Bos sering lebih suka mengarahkan senjata (mengancam) daripada suka menaikkan gaji dan selalu mencari senjata yang lebih besar. Sedangkan, Lead-manager yang efektif tidak pernah menggunakan pesan pemaksaan namun mencoba memberi para pekerja jenis informasi yang akan meyakinkan mereka untuk melakukan apa yang mereka ingin lakukan karena hal itu lebih menguntungkan mereka dan juga manajer.

Ketika boss-teacher mengeluh bahwa, dari apapun yang mereka lakukan tampaknya tidak bisa memotivasi siswa untuk bekerja keras, maka apa sebenarnya yang mereka katakan adalah bahwa mereka tidak berhasil memberi siswa tersebut pesan yang benar. Namun jika kenyataan bahwa siswa memilih untuk tidak melakukan tugas sekolah tidak berarti mereka kurang memiliki motivasi: Tidak ada manusia yang tidak termotivasi. Sebenarnya, setiap makhluk hidup sangat termotivasi sepanjang waktu. Pelajar tidak terkecuali dengan teori kontrol aksioma bahwa semua mahluk hidup selalu termotivasi oleh kebutuhan dasar spesies mereka. Tetapi setiap makhluk hidup, termasuk siswa, tidak harus termotivasi untuk melakukan apa yang anda, saya, atau siapa pun kalau tidak harus mau melakukannya.

Perbedaan penting antara boss-manager dan lead-manager adalah terutama bagaimana mereka memahami motivasi. Untuk memahami motivasi sebenarnya. Perlu untuk memahami bahwa teori kontrol berpendapat bahwa semua manusia dilahirkan dengan kebutuhan dasar hidup yang dibangun dalam struktur genetik mereka: kelangsungan hidup, cinta, kekuasaan, kesenangan dan kebebasan. Sepanjang hidup kita, kita harus berusaha hidup dengan cara yang terbaik untuk memenuhi satu atau lebih dari kebutuhan ini.

Teori kontrol adalah istilah deskriptif karena kita mencoba untuk mengendalikan perilaku kita sendiri sehingga apa yang kita pilih untuk dilakukan adalah hal yang paling dibutuhkan - hal yang memuaskan yang dapat kita lakukan saat itu. Meskipun kita hanya dapat mengendalikan perilaku kita sendiri, namun jelas bahwa banyak dari apa yang kita pilih adalah usaha untuk mengendalikan orang lain. Sebagai contoh, banyak dari kita mencoba untuk menghentikan orang yang kita cintai untuk menghancurkan diri dengan obat-obatan yang adiktif. Tapi untuk melakukan ini kita bisa mengendalikan dari hanya apa yang dapat kita lakukan. Teori kontrol, oleh karena itu, adalah penjelasan dari usaha terus-menerus untuk 
mengendalikan diri kita dan orang lain, meskipun dalam praktiknya kita hanya bisa mengendalikan diri kita sendiri.

Glasser mengingatkan bahwa "kontrol" dalam konteks ini berarti mengendalikan seperti menyetir mobil atau mengikuti resep. Itu tidak berarti mendominasi dengan menggunakan kekerasan atau ancaman kekuatan, seperti yang dilakukan polisi untuk menaklukkan penjahat. Bisa saya katakan, "Saya memaksa diri saya sendiri," kita tidak benar-benar menggunakan kekuatan pada diri kita sendiri. Yang kita maksud adalah bahwa sangat sulit bagi kita untuk memilih melakukan seperti yang kita lakukan.

Glasser menjelaskan lebih lanjut bahwa gen kita, yang intinya adalah petunjuk biologis untuk apa kita menjadi, tidak hanya mendikte struktur kita (misalnya warna mata kita) tapi juga (dan klaim ini unik untuk teori kontrol) bagaimana kita, sebagai manusia, harus berusaha untuk menjalani hidup kita. Sama seperti burung pemangsa utara harus selalu berusaha keras ke selatan untuk musim dingin, kita juga harus berusaha menjalani hidup kita dengan cara yang kita percaya akan paling memuaskan kebutuhan kita. Masalahnya adalah bahwa kebutuhan genetik sendiri tidak tahu apa-apa tentang nanti: Mereka terus mendorong kita untuk melakukan apa yang terasa baik sekarang. Glasser mengumpamakan; Anda bisa memberi tahu perut Anda bahwa Anda tidak akan memberi makan karena Anda ingin menurunkan berat badan, tapi Anda tidak bisa menghentikan perut Anda untuk mengatakan bahwa Anda menginginkan makanan saat ini. Ukuran kekuatan kita, yang sering disebut kekuatan karakter, adalah seberapa banyak kita dapat belajar menoleransi rasa sakit atau menunda kesenangan sambil melakukan apa yang "baik" bagi kita dalam jangka panjang.

Seorang lead-manager yang baik dapat memprediksi berapa banyak rasa sakit yang akan dialami seorang pekerja saat ini dan masih terus bekerja keras untuk mendapatkan hasil di masa depan. Dalam hal bagaimana mereka menangani kepuasan-kebutuhan orang-orang yang mereka kelola, ada perbedaan mencolok antara boss-manager dan lead-manager. Bossmanager memberi tahu orang apa yang harus mereka lakukan dan bagaimana melakukannya. Mereka juga mengatakan kepada pekerja bahwa itu adalah hal terbaik yang harus dilakukan pada saat itu, boss-manager menyiratkan bahwa melakukan apa yang mereka katakan adalah cara terbaik agar pekerja merasa baik (atau untuk memenuhi kebutuhan mereka).

Pada dasarnya, boss-teacher tidak begitu memperhatikan kebutuhan siswa. Guru jenis ini tidak bekerja untuk berteman dengan siswa dan melihat pekerjaan itu lebih penting daripada suasana di mana hal itu dilakukan. Bertolak belakang dengan saran Deming, leadteacher bekerja pada siswa, bukan pada sistem. Bahkan agar terlihat adil, boss-teachers bersedia memberi penghargaan kepada pekerja yang bekerja keras dan melakukannya dengan 
baik, namun, seperti yang dibahas di bab sebelumnya, kecuali nilai bagus, ada beberapa penghargaan yang tersedia bagi siswa. Apapun imbalan lainnya yang mereka gunakan, para bos cenderung memutuskannya sendiri dan jarang mencoba untuk mencari tahu dari murid mereka apa penghargaan ini sesuai dengan keinginan siswa. Para bos memutuskan apa imbalannya, dan seringkali tidak sesuai kebutuhan-kepuasan para siswa sebagaimana diyakini oleh bos.

Pada dasarnya, boss-manager memberitahu para pekerja bahwa mereka tahu apa yang terbaik bagi mereka dan bahwa mereka bersedia menggunakan kekuatan apa yang harus mereka paksakan untuk menyelesaikan pekerjaan, terlepas dari kebutuhan mereka. Sementara beberapa orang mungkin memiliki kebutuhan yang lebih kuat daripada yang lain, misalnya, beberapa orang tampaknya menginginkan lebih banyak cinta atau lebih banyak kekuatan daripada yang lain, dalam kebanyakan kasus perbedaan ini tidak signifikan.

Seperti boss-manager, lead-managers memiliki tujuan membuat pekerja mereka bekerja keras, tapi untuk melakukannya mereka terus-menerus memikirkan kebutuhan para pekerja. Glasser menggambarkan hal ini dengan deskripsi bagaimana seorang guru aljabar hipotetis dapat membujuk lebih banyak siswa untuk mempelajari materi. Glsser berpikir akan bermanfaat untuk meninjau contoh itu dan menunjukkan bagaimana pendekatan ini berkaitan dengan kebutuhan dasar. Sejak hari pertama, lead- teacher mencoba menciptakan situasi kerja yang hangat dan bersahabat dan sama sekali tanpa paksaan. Siswa dengan cepat menyadari bahwa guru ini bukan musuh mereka dan tidak berusaha memuaskan kebutuhannya akan kekuasaan dengan cara memerintah mereka.

Selama mereka mau bekerja keras, gurunya akan melindunginya dari orang lain yang yang akan menjadi bos mereka. Misalnya, jika siswa belajar tapi juga berisik, guru utama akan melindungi mereka dari administrator yang menganggap bahwa satu-satunya pekerjaan yang baik adalah pekerjaan yang sepi. Kelas mungkin bising karena lead-teacher mengajar dalam kelompok kooperatif, dan penelitian menunjukkan bahwa ketika ada banyak interaksi, seringkali bising, siswa belajar lebih banyak. Guru juga mendorong siswa untuk bekerja sama di rumah karena banyak tidak mengerjakan pekerjaan rumah jika harus melakukannya sendiri. Di kelas, guru beralih dari satu kelompok ke kelompok lainnya dan mengenal setiap siswa dengan cara yang tidak mungkin dilakukan hanya dengan memberi ceramah atau menugaskan meja kerja individu. Sambil mengenal para siswa, guru terus mencari cara mengajar yang lebih baik dan meminta masukan mereka tentang bagaimana keadaan ini.

Lead-teacher menekankan bahwa meskipun aljabar itu sulit, hal itu jauh dari tidak mungkin. Ini tidak membutuhkan bakat khusus, dan semua yang bekerja akan bisa 
mempelajarinya dengan baik. Baik di kelas maupun di pekerjaan rumah mereka, guru berusaha keras untuk tidak membiarkan siswa menyelesaikan sesuatu yang kurang dari mendapatkan pekerjaan mereka dengan benar, bahkan jika hanya ada satu masalah. Tapi yang lebih penting daripada menjawab masalah dengan benar adalah memahami apa yang mereka lakukan untuk mewujudkannya. Penekanannya pada mengetahui bagaimana mengerjakan matematika dan di mana hal itu bisa diterapkan dalam kehidupan mereka.

Lead-teacher juga menjelaskan bahwa satu-satunya tujuan nilai adalah untuk menunjukkan apa yang siswa ketahui. (Nilai akan dibahas secara luas di Bab Delapan.) Nilai rendah tidak berarti kegagalan; Artinya siswa belum cukup belajar. Sampai nilai akhir, semua nilai bersifat sementara: Setiap nilai rendah di sepanjang jalan bisa dan harus ditingkatkan. Dengan menunjukkan bahwa mereka tahu lebih banyak daripada yang mereka lakukan, siswa akan mendapatkan nilai yang lebih tinggi untuk mengganti yang rendah. Guru menjelaskan bahwa dia secara pribadi membenci nilai rendah dan suka memberikan yang lebih tinggi: Semua siswa harus melakukannya dan bersedia melakukan pekerjaan itu. Dengan demikian guru menunjukkan bahwa nilai akan digunakan untuk memberdayakan, tidak pernah sebagai senjata atau sebagai hukuman. Hal ini sangat berbeda dengan pengajaran bos: Siswa sering kali merasa kehilangan kekuatan dan frustrasi karena nilai rendah digunakan untuk menghukum dan tidak pernah dinaikkan.

Meski ditekankan pada kerja keras, suasana kelas tidak pernah suram. Suasana hati yang ingin diciptakan oleh lead-teacher adalah kesenangan: Selama kita harus bekerja, mari bersenang-senanglah sepanjang jalan. Lead-manager, bagaimanapun, jauh lebih rela daripada boss-manager untuk membiarkan para pekerja memiliki peran dalam menentukan bagaimana cara terbaik untuk melakukan pekerjaan itu. Untuk mencapai hal ini, lead-teacher menghabiskan sebagian kecil dari hampir setiap kelas untuk meminta masukan kepada siswa tentang seberapa banyak yang dapat dipelajari atau apa yang dapat dilakukan untuk membuat kelas lebih menyenangkan. Guru tidak menolak setiap ada gagasan penghargaan namun percaya bahwa kelas harus menentukan penghargaannya sendiri jika menilai bahwa sudah melakukan pekerjaan yang baik. Siswa didorong untuk merencanakan kegiatan baik di dalam maupun di luar kelas sebagai hadiah untuk melakukan pekerjaan yang baik, dan guru menghadiri beberapa kumpul-kumpul di luar kelas sebagai bagian dari komitmen terhadap keseluruhan proses sosial dimana dia merupakan bagian yang penting.

Lead-teacher menyadari bahwa kebutuhan yang paling terpuaskan dengan cara pengajaran ini adalah untuk kita semua yang paling sulit memuaskan-kekuatan dan rasa memiliki - dan selalu berusaha membantu siswa memenuhi kebutuhan ini saat mereka 
bekerja. Lead-teacher menerima apa yang oleh boss-teacher sulit terima - semakin besar kekuatan yang diberikan guru, semakin sedikit yang harus dia gunakan untuk bos siswa. Kekuatan sebenarnya berasal dari persepsi siswa tentang guru yang kompeten dalam melakukan pekerjaan, yaitu menunjukkan dan memberi model apa yang harus dilakukan dan menciptakan lingkungan yang baik untuk bekerja. Siswa menghargai kenyataan bahwa leadteacher tidak pernah mengancam atau menghukum, namun mengatakan bahwa jika ada masalah, "Kami akan menyelesaikannya." Kebutuhan guru yang memimpin memenuhi syarat dipekerjakan oleh pekerjaan dengan baik, bukan karena siswa menjadi patuh.

Glasser: Dengan asumsi bahwa administrator perlu memanage guru dengan cara yang sama seperti yang saya sarankan bagaimana guru memanage siswa. Apa yang mereka katakan adalah bahwa pengajaran dan pengelolaan semacam ini bertentangan dengan premis boss-manager tradisional yang tampaknya mendominasi pendidikan: Baik siswa maupun guru tidak dapat dipercaya untuk melakukan yang terbaik untuk mereka; Mereka harus diberi tahu apa yang harus dilakukan dan dipaksa melakukannya. Oleh karena itu, bahkan saat leadteacher mendapatkan hasil, seperti yang mereka lakukan secara konsisten, apa yang mereka lakukan untuk mendapatkan hasil ini dapat dilihat sebagai ancaman bagi mereka yang mengepalai mereka dan boss-teacher yang mengajar di samping mereka. Bahkan jika muridmuridnya bekerja, lead-teacher mungkin diberitahu bahwa disiplinnya masih lemah karena ada tawa di kelasnya. Jika dia kreatif, karena dia harus mengajar dengan cara yang memuaskan, dia akan diberitahu bahwa dia menyimpang dari cara yang telah teruji untuk merencanakan pelajarannya, yaitu memberi kuliah dan memberi kerja kepada siswa untuk melakukan sendiri di meja mereka.

Lead-teacher juga akan dikritik karena terlalu memperhatikan dan mengatakan bahwa terlalu banyak keterlibatan pribadi atau tidak profesional. Dia akan diingatkan untuk menyimpan tes penilaian negara dan memikirkan fragmen subjek sehingga siswa akan lebih baik dalam tes ini, walaupun pendekatan ini gagal menarik perhatian lebih dari separuh siswa. Dia akan segera belajar bahwa di sekolah-sekolah (dan juga di dunia) yang didominasi oleh manajer bos, dia tidak akan populer untuk apa yang dia percaya dan terutama untuk apa yang dia lakukan. Dia akan melihat banyak boss-teachers gagal total, tapi kebanyakan dari mereka yang menjalankan sistem akan terus mendukung apa yang boss-teacher lakukan dengan benar dan mengkritiknya sebagai salah.

Pemikiran bos semacam inilah yang mengarah pada premis yang benar-benar merusak bahwa sekolah perlu diperjuangkan antara para guru (atasan) dan para siswa (pekerja), Dan jika para atasan rileks bahkan untuk sesaat para siswa akan menghancurkan sekolah. Tapi 
kebenaran yang menyedihkan adalah bahwa banyak sekolah kita sudah sangat dekat untuk dihancurkan: Beberapa sekolah kota pusat kita bahkan tidak lagi memiliki tempat belajar. Semakin kita bergantung pada boss-manager untuk memecahkan masalah, semakin kita akan kehilangan sedikit pun yang kita miliki.

\section{Sumber:}

Glasser, W. (1992). The Quality School: Managing Students Without Coercion. (2nd ed.). New York: Harper Perennial - HarperCollins Publishers, Inc. 